\title{
Radioactivity in Seawater - A Review from Kuwait
}

\author{
By Saif Uddin* \\ Montaha Behbehanit \\ A. $A b a^{*}$
}

The Gulf waters of the region are extremely important for desalination to meet its freshwater needs. There are large desalination facilities installed along the western Gulf coast, with a cumulative desalination capacity of the countries in the Arabian Gulf being approximately $11 \mathrm{~m} 3 / \mathrm{d}$. Radioactivity monitoring in the marine environment becomes very important in the Gulf region due to the fact that the Gulf states are moving towards a nuclear energy option. The first nuclear power plant in Bushehr, Iran, has been operational since 2011 and others are commissioned in Abu Dhabi and Saudi Arabia. This study presents the first radionuclide baseline in the northern Gulf waters (considered as pre-nuclear) and is expected to be a valuable dataset for future monitoring works in this region. The concentrations range of Tritium, Strontium-90, Polonium-210, Lead-210, Cesium-137, Potassium-40, Uranium-238, and Uranium-234 in the northern Gulf waters were $0.14-0.15,0.57-0.78,0.48-0.68,0.75-0.89,1.25$ - 1.38 and $89-93 \mathrm{mBq} / \mathrm{l}$, respectively. The low levels of tritium in the region can be attributed to limited atmospheric tritium fallout due to low precipitation and the lack of nuclear power plants (NPPS) until 2011 in the area. The most likely source of strontium-90 concentration in the Gulf waters is long-range transport. The concentrations of 210Po in seawater ranged between 0.48 and $0.68 \mathrm{mBq} / \mathrm{l}$; however, there is a seasonal fluctuation that has also been observed. The 137Cs concentration in this area is comparable to that reported for the Pacific and the Indian Oceans, i.e., between 0.1 and $2.8 \mathrm{mBq} /$ during the year 2000 (Povinec et al., 2005). The current baseline data generated suggest that the levels of these different radionuclides in Kuwait's seawater are comparable to their levels in other marine waters in the northern hemisphere (IAEA, 2001). The low levels of radionuclides ensure the radiological safety of desalinated water and seafood.

Keywords: 137Cs, 90Sr, 210Po, 210Pb, Uranium

\section{Introduction}

The Gulf waters are extremely important for desalination to meet the freshwater needs in the region. There are large desalination facilities installed along the western Gulf coast, with a cumulative desalination capacity of the countries in the Arabian Gulf being approximately $11 \mathrm{~m}^{3} / \mathrm{d}$ (Lattemann and Höpner, 2008; Uddin et al., 2010). Radionuclide monitoring in the marine

\footnotetext{
${ }^{*}$ Research Scientist, Kuwait Institute for Scientific Research, Kuwait.

${ }^{\dagger}$ Associate Research Scientist, Kuwait Institute for Scientific Research, Kuwait.

${ }^{*}$ Research Specialist at Kuwait Institute for Scientific Research, Kuwait.
} 
environment is a matter of prime concern for the northern Gulf states due to the fact that several countries are moving towards the nuclear energy option. The first nuclear power plant in Bushehr, Iran, is already operational and others are likely to be commissioned soon in Abu Dhabi and Saudi Arabia. Various researchers have looked at radionuclide concentration in seawater from the region (Al-Ghadban et al., 2011; Al-Qaradawi et al., 2015; Al-Zamel et al., 2005; Uddin et al., 2012a; Uddin et al., 2013b). This study presents the radionuclide baseline in the northern Gulf waters (considered as pre-nuclear) and is expected to be a valuable dataset for future monitoring work in this region. The comprehensive baseline measurements for ${ }^{210} \mathrm{Po},{ }^{210} \mathrm{~Pb},{ }^{137} \mathrm{Cs},{ }^{90} \mathrm{Sr}$, and ${ }^{3} \mathrm{H}$ were established for the Gulf waters (Figure 1).

\section{Methods}

Water samples were collected from six sites at a depth of $1 \mathrm{~m}$ below the sea surface using 5-1 Niskin bottles. The water sampler was manually lowered to the sampling depth and then opened. Once full, the sampler was raised and the seawater was transferred into appropriate containers, acidified, and stored. From each location, 1001 of seawater were transferred into five containers of 201 each. The containers were labeled with date and time, and the Global Positioning System (GPS) locations and sample IDs were noted. Then, the containers were sealed. Standard procedures were followed for the measurement of the radionuclides. Tritium $\left({ }^{3} \mathrm{H}\right)$ was measured by liquid scintillation spectrometry using a Quantalus 1210 instrument after electrolytic enrichment following the procedure developed by Ostlund and Werner (Ostlund and Werner, 1962). This method is precise and useful for environmental samples with low ${ }^{3} \mathrm{H}$ concentrations. The lower detection limit for this method is 0.2 tritium unit (TU), corresponding to $0.025 \mathrm{~Bq} / \mathrm{l}$ for a 100 min count (Al Ghadban et al., 2010). For ${ }^{137} \mathrm{Cs}$ determination, the ammonium molybdophosphate (AMP) method developed by Yamagata (Yamagata, 1963) was used. This method is extensively used in marine environmental studies (Aarkrog et al., 1983; Jefferies and Steele, 1989; Molero et al., 1993). A lowlevel gamma spectrometry system with a germanium detector was used for ${ }^{137} \mathrm{Cs}$ determination in various environmental matrices. The seawater samples were not filtered; therefore, the total radionuclide concentration was determined. ${ }^{210} \mathrm{Po}$ in the seawater samples was analyzed using a radiochemical method developed by Bojanowski et al. (Bojanowski et al., 1983), and a twelve-chamber alpha spectrometry system from Canberra was used for counting the samples. Strontium $\left({ }^{90} \mathrm{Sr}\right)$ was determined by yttrium in-growth and beta-ray spectrometry (La Rosa et al., 2001).

As part of the quality assurance/quality control (QA/QC) procedures, blank and spiked samples were used as controls for each batch of analysis. The radiometrics group had also participated in an interlaboratory comparison exercise and a proficiency testing program organized by the International Atomic Energy Agency (IAEA) for external assessment. Some of the results 
obtained for the IAEA proficiency testing IAEA-TEL-2014-03 at our laboratory for ${ }^{238} \mathrm{U},{ }^{234} \mathrm{U},{ }^{210} \mathrm{~Pb},{ }^{137} \mathrm{Cs}$ and ${ }^{241} \mathrm{Am}$ were $1.93 \pm 0.08 \mathrm{~Bq} \mathrm{~kg}^{-1}, 1.93$ $\pm 0.079 \mathrm{~Bq} \mathrm{~kg}^{-1}, 23.12 \pm 1.3 \mathrm{~Bq} \mathrm{~kg}^{-1}$ and $15.87 \pm 0.52 \mathrm{~Bq} \mathrm{~kg}^{-1}$, respectively, compared to the corresponding IAEA certified values of $1.98 \pm 0.01,1.91 \pm$ $0.01,22.96 \pm 0.45$ and $16.25 \pm 0.2$ indicating that our analyses successfully passed all these tests.

Figure 1. Sampling Locations

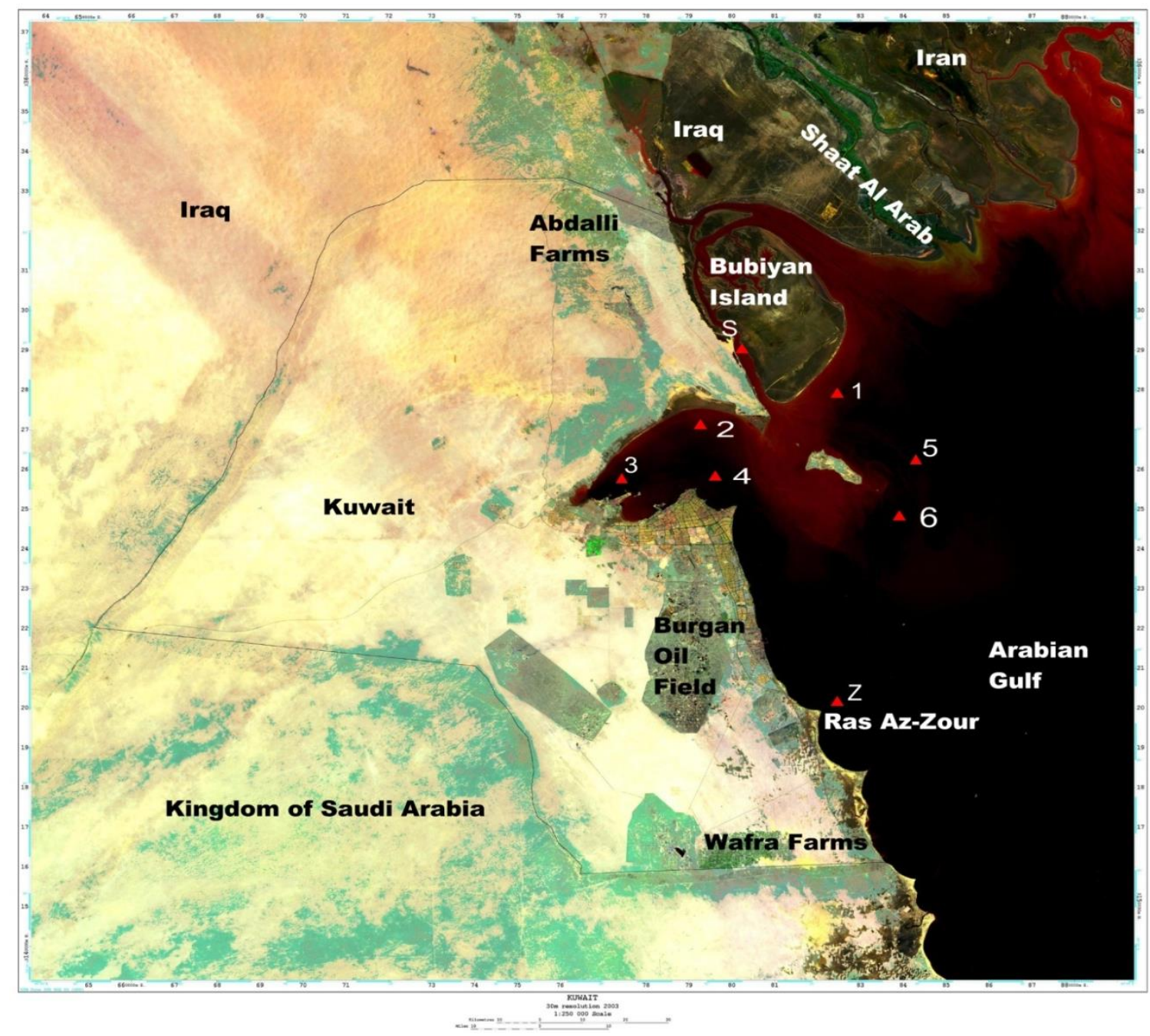

\section{Results and Discussion}

The radionuclide concentrations in seawater are presented in Table 1. The low baseline levels of tritium in the region (1.11 to $1.25 \mathrm{TU})$ can be attributed to limited atmospheric tritium fallout due to the very low amount of precipitation in Kuwait. The major sources of tritium discharge are the NPPs, and there has been only one NPP operational since 2011 in the area. The likely fallout from the atmospheric nuclear testing in the 1950s and 1960s has 
decayed significantly due to the short half-life of tritium (12.32 y) resulting in this low baseline. Natural (pre-nuclear age) levels of tritium in precipitation are on the order of 1-5 TU (EPA, 2006).

Strontium-90 concentration in Kuwait's territorial waters ranged between 0.57 and $0.78 \mathrm{mBq} / 1$, with the most likely source being long-range transport. Stable strontium, also measured in seawater, ranged between 8.94 and 9.60 ppm (Uddin et al., 2013b), higher than the average oceanic concentration of stable strontium of $\sim 8 \mathrm{ppm}$. The ${ }^{87} \mathrm{Sr} /{ }^{86} \mathrm{Sr}$ ratio is a strong indicator of geochemical processes (Shields, 2007) with modern day seawater having a ratio of $\sim 0.709$. There are two major sources of strontium, i.e. a submarine, chemical alteration giving a characteristic ${ }^{87} \mathrm{Sr} /{ }^{86} \mathrm{Sr}$ ratio of 0.703 (Hofmann, 1997), and the subaerial chemical weathering of the continental crust and sedimentary cover resulting in a ${ }^{87} \mathrm{Sr} /{ }^{86} \mathrm{Sr}$ ratio of $\sim 0.712$ (Palmer and Edmond, 1989; Peucker-Ehrenbrink and Miller, 2006). The ${ }^{87} \mathrm{Sr} /{ }^{86} \mathrm{Sr}$ ratios in Kuwait's waters ranged between 0.709128 and 0.709157 (Table 2), suggesting a strontium origin from carbonate rock dissolution, possibly due to excessive sediment input from the northern rivers that includes Karun, Shaat Al Arab, Shaat Al Basra and also due to the acidification of the Gulf waters (Uddin et al., 2012a; Uddin et al., 2008; Uddin et al., 2012b; Uddin et al., 2012c).

Polonium is also found in the earth's crust in low concentrations and is quite frequently associated with phosphates. There are many isotopes of polonium; but in this study, ${ }^{210} \mathrm{Po}$ was considered because the bulk of Po uptake is from this isotope, its half-life is $138 \mathrm{~d}$, and its specific activity is quite high $(4500 \mathrm{ci} / \mathrm{g})$. Another factor for considering ${ }^{210} \mathrm{Po}$ was that it originates as a decay product of ${ }^{222} \mathrm{Ra}$ and ${ }^{226} \mathrm{Ra}$. The radon concentration in Kuwait is reasonably high, and its decay product is expected to be deposited in both the terrestrial and the marine environment. The baseline concentrations of ${ }^{210} \mathrm{Po}$ in seawater ranged between 0.48 and $0.68 \mathrm{mBq} / \mathrm{l}$; however, there is a seasonal fluctuation that has also been observed (Uddin and Behbehani, 2014).

The ${ }^{90} \mathrm{Sr}$ concentration in Kuwait's seawater ranged between 0.57 and 0.78 $\mathrm{mBq} / \mathrm{l}$, which is comparable to the observations made under the IAEA coordinated Worldwide Marine Radioactivity Studies (WOMARS) in the Pacific and the Indian Oceans (Povinec et al., 2005). The estimated average during the year 2000 was found to be 0.1 to $1.5 \mathrm{mBq} / \mathrm{l}$ (ibid.). The ${ }^{90} \mathrm{Sr}$ concentration in the Arabian Gulf is far less than that reported for the Caspian Sea, where the mean ${ }^{90} \mathrm{Sr}$ concentration during 1995 was $8.0 \pm 1.6 \mathrm{mBq} / \mathrm{l}$ (Povinec et al., 2003). This average concentration appeared to be higher than that expected from the global fallout in this latitude belt (IAEA, 2001) and was mainly attributed to river input suggesting the remobilization of ${ }^{90} \mathrm{Sr}$ from the catchment area.

The ${ }^{137} \mathrm{Cs}$ concentration in Kuwait's marine waters ranged between 1.25 and $1.38 \mathrm{mBq} / \mathrm{l}$. This range in concentration is comparable to that reported for the Pacific and the Indian Oceans, i.e., between 0.1 and $2.8 \mathrm{mBq} / \mathrm{l}$ during the year 2000 (Povinec et al., 2005). 


\section{Conclusions}

The current baseline data generated suggest that the levels of the aforementioned different radionuclides in Kuwait's seawater are comparable to their levels in other marine waters in the northern hemisphere (IAEA, 2001). A seasonal drop in the ${ }^{210}$ Po concentration in seawater was observed to vary with the abundance of phytoplankton and macroalgae leading to biological dilution. ${ }^{90} \mathrm{Sr}$ concentration is low in Gulf waters. The ${ }^{137} \mathrm{Cs}$ concentration in seawater was also reasonably low; hence, such low levels provide an opportunity to use this radionuclide as an indicator for any future radiocesium releases in this region. 
Table 1. Radionuclide Concentrations in Kuwait's Seawater Sampled in 2010 and 2013

\begin{tabular}{|c|c|c|c|c|c|c|c|c|}
\hline Station & $\begin{array}{c}{ }^{3} \mathbf{H}(\mathrm{TU}) \\
2013\end{array}$ & $\begin{array}{c}{ }^{90} \mathrm{Sr}(\mathrm{mBq} / \mathrm{l}) \\
2013\end{array}$ & $\begin{array}{c}{ }^{210} \mathrm{Po}(\mathrm{mBq} / \mathrm{l}) \\
2013\end{array}$ & $\begin{array}{c}{ }^{210} \mathrm{~Pb}(\mathrm{mBq} / \mathrm{l}) \\
2013\end{array}$ & $\begin{array}{c}{ }^{137} \mathrm{Cs}(\mathrm{mBq} / \mathrm{l}) \\
2010\end{array}$ & $\begin{array}{c}{ }^{40} \mathrm{~K}(\mathrm{mBq} / \mathrm{l}) \\
2010\end{array}$ & ${ }^{238} \mathrm{U}(\mathbf{m B q} / \mathbf{l})$ & ${ }^{234} \mathrm{U}(\mathrm{mBq} / \mathrm{l})$ \\
\hline 1 & $1.22 \pm 0.01$ & $0.68 \pm 0.06$ & $0.49 \pm 0.06$ & $0.78 \pm 0.05$ & $1.34 \pm 0.14$ & $90 \pm 7$ & - & - \\
\hline 2 & $1.17 \pm 0.01$ & $0.73 \pm 0.05$ & $0.68 \pm 0.08$ & $0.89 \pm 0.03$ & $1.36 \pm 0.18$ & $89 \pm 8$ & - & - \\
\hline 3 & $1.21 \pm 0.01$ & $0.65 \pm 0.05$ & $0.54 \pm 0.08$ & $0.83 \pm 0.04$ & $1.25 \pm 0.18$ & $92 \pm 8$ & - & - \\
\hline 4 & $1.22 \pm 0.01$ & $0.78 \pm 0.10$ & $0.63 \pm 0.02$ & $0.86 \pm 0.04$ & $1.38 \pm 0.14$ & $91 \pm 9$ & - & - \\
\hline 5 & $1.11 \pm 0.01$ & $0.77 \pm 0.08$ & $0.68 \pm 0.02$ & $0.89 \pm 0.02$ & $1.34 \pm 0.14$ & $93 \pm 8$ & - & - \\
\hline 6 & $1.22 \pm 0.01$ & $0.61 \pm 0.08$ & $0.64 \pm 0.20$ & $0.87 \pm 0.06$ & $1.35 \pm 0.18$ & $91 \pm 8$ & - & - \\
\hline$S$ & $1.25 \pm 0.01$ & $0.57 \pm 0.05$ & $0.48 \pm 0.07$ & $0.75 \pm 0.05$ & - & - & - & - \\
\hline $\mathrm{Z}$ & $1.19 \pm 0.01$ & $0.68 \pm 0.10$ & $0.49 \pm 0.08$ & $0.77 \pm 0.04$ & - & - & - & - \\
\hline 7 & - & - & - & - & - & - & $0.040 \pm 0.005$ & $0.054 \pm 0.006$ \\
\hline Range & $1.17-1.25$ & $0.57-0.78$ & $0.48-0.68$ & $0.75-0.89$ & $1.25-1.38$ & 9-93 & & \\
\hline
\end{tabular}


Table 2. ${ }^{87} \mathrm{Sr} /{ }^{86} \mathrm{Sr}$ Concentration Ratios in Kuwait's Seawater

\begin{tabular}{ccc}
\hline Station & ${ }^{\mathbf{8 7}} \mathbf{S r} /{ }^{\mathbf{8 6}} \mathbf{S r}$ & Uncertainty \\
\hline 1 & 0.709143 & 0.000006 \\
2 & 0.709151 & 0.000013 \\
3 & 0.709128 & 0.000010 \\
4 & 0.709138 & 0.000009 \\
5 & 0.709157 & 0.000011 \\
6 & 0.709140 & 0.000013 \\
$Z$ & 0.709154 & 0.000007 \\
$S$ & 0.709153 & 0.000013
\end{tabular}

Source: (Uddin et al., 2013a)

\section{Acknowledgments}

Authors are thankful to the Director General, the Kuwait Institute for Scientific Research, and the Executive Director, Environment and Life Sciences Research Center, for supporting this study, EM058K.

\section{References}

Aarkrog, A., Dahlgaard, H., Hallstadius, L., Hansen, H., Holm, E., 1983. Radiocesium from Sellafield effluents in Greenland waters. Nature 303, 49-51.

Al Ghadban, A., Uddin, S., Aba, A., L.N., A., Al Shamroukh, D., Al Mutairi, A., Al Khabbaz, A., Behbehani, M., 2010. Measurement and Assessment of Radionuclide Concentration in the Coastal Marine Environment. Kuwait Institute for Scientific Research, Kuwait, pp. 1- 49.

Al-Ghadban, A., Uddin, S., Aba, A., Ali, L.N., Al-Shamroukh, D., Al-Khabbaz, A., Al-Mutairi, A., 2011. Measurement and Assessment of Radionuclide Concentrations in the Coastal Marine Environment. Kuwait Institute for Scientific Research KISR 10540, 128p.

Al-Qaradawi, I., Abdel-Moati, M., Al-Ansi Al-Yafei, M., Al-Ansari, E., AlMaslamani, I., Holm, E., Al-Shaikh, I., Mauring, A., Pinto, P.V., Abdulmalik, D., Amir, A., Miller, M., Yigiterhan, O., Persson, B., 2015. Radioactivity levels in the marine environment along the Exclusive Economic Zone (EEZ) of Qatar. Marine Pollution Bulletin 90, 323-329.

Al-Zamel, A.Z., Bou-Rabee, F., Olszewski, M., Bem, H., 2005. Natural radionuclides and ${ }^{137} \mathrm{Cs}$ activity concentration in the bottom sediment cores from Kuwait Bay. Journal of Radioanalytical and Nuclear Chemistry 266, 269-276.

Bojanowski, R., Fukai, R., Ballestra, S., Asari, H., 1983. Determination of natural radioactive elements in marine environmental material by ion-exchange and alpha spectrometry. International Atomic Energy Agency, RAS7018 Report No. 74, Vienna.

EPA, U., 2006. http://www.epa.gov/safewater/dwh/index.html. 
Hofmann, A.W., 1997. Mantle geochemistry: the message from ocean volcanism. Nature 385, 219-229.

IAEA, 2001. Worldwide marine radioactivity studies (WOMARS). IAEA-MEL, Monaco.

Jefferies, D.F., Steele, A.K., 1989. Observed and predicted concentrations of caesium137 in seawater pf the Irish Sea 1970 - 1985. Journal of Environmental Radioactivity 10, $173-189$.

La Rosa, J.J., Burnett, W., Lee, S.H., Levy, I., Gastaud, J., Povinec, P.P., 2001. Separation of actinides, caesium and strontium from marine samples using extraction chromatography and sorbents. Journal of Radioanalytical and Nuclear Chemistry 248, 765-770.

Lattemann, S., Höpner, T., 2008. Environmental impact and impact assessment of seawater desalination. Desalination 220, 1-15.

Molero, J., Moran, A., Sánchez-Cabeza, J.A., Blanco, M., Mitchell, P.I., VidalQuadras, A., 1993. Efficiency of radiocaesium concentration from large volume natural water samples by scavenging with ammonium molybdophosphate. Radiochimica Acta 62, 159 - 162.

Ostlund, H.G., Werner, E., 1962. The Electrolytic Enrichment of Tritium and Deuterium for Natural Tritium Measurements. International Atomic Energy Agency, Vienna

Palmer, M.R., Edmond, J.M., 1989. Strontium isotope budget of the modern ocean. Earth Planetary Science Letters 92, 11-26.

Peucker-Ehrenbrink, B., Miller, M.W., 2006. Marine ${ }^{87} \mathrm{Sr} /{ }^{86} \mathrm{Sr}$ record mirrors the evolving upper continental crust. Geochim. Cosmochim Acta 70, A487.

Povinec, P.P., Froehlich, K., Gastaud, J., Oregioni, B., Pagava, S.V., Pham, M.I., Rusetski, V., 2003. Distribution of ${ }^{90} \mathrm{Sr},{ }^{137} \mathrm{Cs}$ and ${ }^{239,240} \mathrm{Pu}$ in Caspian Sea water and biota. Deep-Sea Research II 50, 2835-2846.

Povinec, P.P., Aarkrog, A., Buesseler, K.O., Delfanti, R., Hirose, K., Hong, G.H., Ito, T., Livingston, H.G., Nies, H., Noshkin, V.E., Shima, S., Togawa, O., $2005 .{ }^{90} \mathrm{Sr}$, ${ }^{137} \mathrm{Cs}$ and ${ }^{239,240} \mathrm{Pu}$ concentration surface water time series in the Pacific and Indian Oceans e WOMARS results. Journal of Environmental Radioactivity 81 (2005) 63e87 81, 63-87.

Shields, G.A., 2007. A normalised seawater strontium isotope curve: possible implications for Neoproterozoic-Cambrian weathering rates and the further oxygenation of the Earth. eEarth 2, 35-42.

Uddin, S., Al Shamroukh, D., Bu Shaiba, A., Al Khabbaz, A., Al Mutairi, A., Al Yagoub, A., 2008. Assessment and Monitoring of Water Quality for the Khairan Pearl City Project, Phase II. Kuwait Institute for Scientific Research.

Uddin, S., Al-Ghadban, A.N., Al Khabbaz, A., 2010. Localized Hyper Saline Waters in Arabian Gulf from Desalination activity - An example from South Kuwait. Environmental Monitoring and Assessment 181, 587-594.

Uddin, S., Al Ghadban, A.N., Aba, A., Behbehani, M., 2012a. Concentration of selected radionuclides in seawater from Kuwait. Marine Pollution Bulletin 64, 1261-1264.

Uddin, S., Gevao, B., Al-Ghadban, A.N., Nithyanandan, M., Al-Shamroukh, D., 2012b. Acidification in Arabian Gulf - Insights from $\mathrm{pH}$ and temperature measurements. Journal of Environmental Monitoring 14, 1479-1482.

Uddin, S., Ghadban, A.N.A., Aba, A., Behbehani, M., 2012c. Concentration of selected radionuclides in seawater from Kuwait. Marine Pollution Bulletin 64, 1261-1264. 
Uddin, S., Al-Ghadban, A.N., Behbahani, M., 2013a. Baseline concentrations of strontium and $90 \mathrm{Sr}$ in seawater from the northern Gulf. Marine Pollution Bulletin 75, 301-304.

Uddin, S., Al Ghadban, A.N., Behbahani, M., 2013b. Baseline concentrations of strontium and Sr-90 in seawater from the northern Gulf. Marine Pollution Bulletin 75, 301-304.

Uddin, S., Behbehani, M., 2014. Bioaccumulation of Po-210 in common gastropod and bivalve species from the northern Gulf. Ecotoxicology and Environmental Safety 104, 132-135.

Yamagata, N., 1963. Gamma-ray spectrometric determination of caesium-137 in seawater by using ammonium molybdophosphate as scavenger. Nature 200, 157 $-158$. 
